\title{
台形断面水路に設置された 横越流堰の流量式と係数 \\ DISCHARGE FORMULA AND COEFFICIENT OF SIDE-WEIRS IN A TRAPEZOIDAL MAIN CHANNEL
}

\author{
浦 勝 1 - 小野 博基 $2 \cdot$ 秋山 壽一郎 $^{3} \cdot$ 坂本 真 $^{4}$ \\ Masaru URA, Hiroki ONO, Juichiro AKIYAMA and Shin SAKAMOTO \\ 1正会員 工博 九州工業大学教授 工学部建設社会工学科 (下804 北九州市戸畑区仙水町1番1号) \\ 2学生員 九州工業大学大学院 工学研究科博士前期課程 (同上) \\ 3正会員 Ph.D. 九州工業大学助教授 工学部建設社会工学科 (同上) \\ 4 正会貝 修(工) 鹿島建設株式会社
}

\begin{abstract}
Flow discharge over side-weirs in rectangular channels derived by the De Marchi equation and discharge coefficient for the flow has been estimated through many experimental investigations. In this study the discharge coefficient for the discharge over the side-weir along the main channel with side slope of 1 to $\mathrm{m}$ is obtained from experimentally and theoretically. An empirical formula of discharge coefficient for the considering flow is proposed as functions of Froude number and side slope of the main channel for the range of $F_{1}=0.3 \sim 0.8$ and $m=0 \sim 0.7$.
\end{abstract}

Key Words : side-weir, discharge coefficient, trapezoidal main channel, side slope

\section{1.はじめに}

近年、都市河川における洪水対策の一つとして横 越流堰を用いて洪水調節池にピーク流量を眝留し、 下流側の河道断面不足を補う方法が採用されはじめ ている。この方法は、河道に沿う地域が高度に開発 され、河道改修は困難であるが、河道付近に公園・ グラウンド等があり、その地下を貯留池として利用 可能である場合に用いられる。横越流堰を採用する 理由は、人為的操作を必要としないという最大のメ リットがあるためで、河川の利用に伴う災害の発生 を低コストで防止する重要な施設であるとともに、 衛生工学, 灌激工学など様々な分野でも用いられて いる。

横越流堰について、最初に合理的な研究を行った

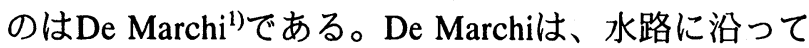
比エネルギーが一定であると仮定した上で、横越流 堰からの越流量を求める流量公式を導いた。しかし、 当初この流量公式はその中に含まれる流量係数 $C_{M}$ の変化についての情報が十分に得られていなかった ため、結果的には信頼性に欠ける公式であった。

しかし、この流量公式が導かれて以降、多くの研 究者がこの $C_{M}$ に着目し、様々な面から研究を行っ

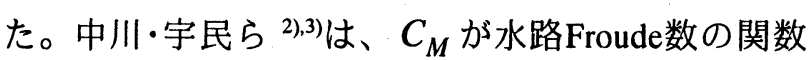
であることを示している。また Subramanya \& Awasthy ${ }^{4}$ は、次元解析によって主流のFroude数，相 対堰長および相対水深が $C_{M}$.支配パラメータであ るが、彼ら自身の実験結果から主流Froude数のみで $C_{M}$ を表示しうることを示している。このように、 これまで横越流堰に関して多くの研究が行なわれて きたが、De Marchiの式は矩形断面水路という条件 で導かれたものであり、 $C_{M}$ に関する知見も、矩形 断面水路で行われた実験より得られたものである。 しかし、多くの都市河川は側壁が傾斜した、いわゆ る台形断面を有する水路・河川である。従って、矩 形断面という制約を受けるDe Marchiの式は、厳密 には適用することができない。

本研究は、台形断面を有する水路に設置された横 越流堰において成立する流量算定式を導き5)、その 式を用いる場合の流量係数 $C_{M}$ の特性を明らかにす るために、側壁勾配 $m$ を0から0.7まで変化させた台 形断面水路において実験を行った。その結果、流量 式中の流量係数 $C_{M}$ は、側壁勾配 $m$ と水路上流 Froude数 $F_{1}$ の関数として定式化された。以下にその 結果を述べる。 


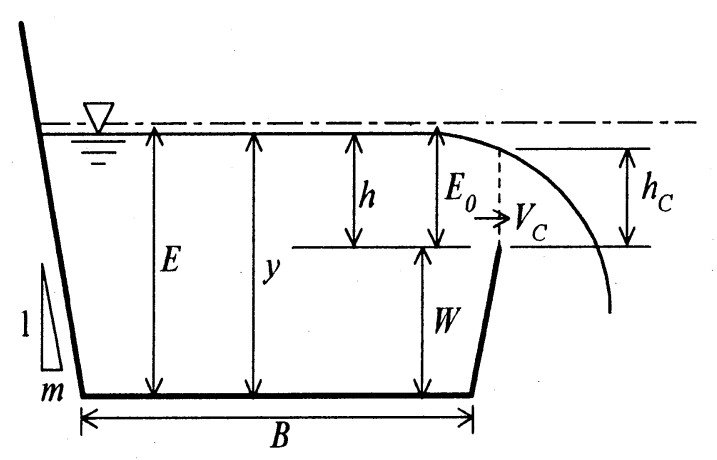

図-1 水路横断面図

\section{2. 理論的考察}

台形断面を有する水路の側壁にある横越流堰を考 える。図-1において、B は水路底面幅， $m$ は側壁 勾配，W は堰高， $y$ は水深である。今、比エネル ギーE が水路に沿って一定であると仮定し"、台形 水路であることを考虑すると、堰のある区間におい て次式が成立する。

$$
\begin{gathered}
E=y+\frac{Q^{2}}{2 g(B+m y)^{2} y^{2}}=\text { const. } \\
-\frac{d Q}{d x}=q
\end{gathered}
$$

ここに、 $Q$ は水路流量, $x$ は水路に沿う距離, $q$ は横越流堰の単位長さあたりの越流量である。また 図-1において、堰の頂点を基準として計った水深 を $h$ とすると堰頂点で限界水深 $h_{C}$ が現れ、その断 面平均流速を $v_{C}$ とすると堰の頂点から計った比エ ネルギー $E_{0}$ は、

$$
E_{0}=h+\frac{v_{a}^{2}}{2 g}=h_{C}+\frac{v_{C}{ }^{2}}{2 g}
$$

と表せる。ここに $v_{a}$ は接近流速である。ここで $F r=v_{C} / \sqrt{g h_{C}}=1$ を用いれば、次式を得る。

$$
E_{0}=h_{C}+\frac{g h_{C}}{2 g}=\frac{3}{2} h_{C}
$$

よって、横越流堰の単位長さあたりの越流量 $q$ は、

$$
q=h_{C} v_{C}=h_{C} \sqrt{g h_{C}}=\frac{2}{3} \sqrt{\frac{2}{3} g} E_{0}^{\frac{3}{2}}
$$

である。また、 $E_{0}=h$ とすることによる補正係数を $C$ とおくことにより式(5)は次のようになる。

$$
q=\frac{2}{3} C \sqrt{\frac{2}{3} g} h^{\frac{3}{2}}=\frac{2}{3} C \sqrt{\frac{2}{3}} g(y-W)^{\frac{3}{2}}
$$

式(6)において、新たに $C_{M}=C / \sqrt{3}$ と書き直し、 流量係数 $C_{M}$ を導入すると次式となる。

$$
-\frac{d Q}{d x}=q=\frac{2}{3} C_{M} \sqrt{2 g}(y-W)^{3 / 2}
$$

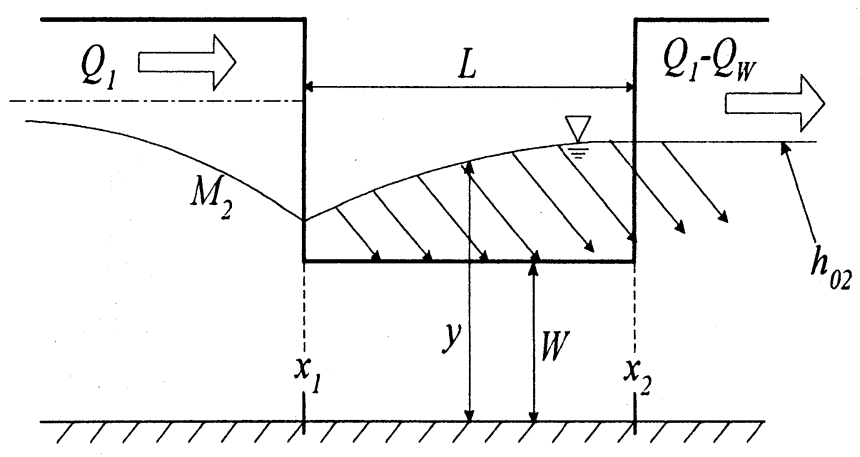

図-2＼cjkstart流出水路（常流）

次に横越流堰のある区間の水面形を図-2のよう に表示して考える。横越流堰の上流端断面を 1 ，下 流端断面を2とし、横越流堰のある区間を検査空間 とする。検查空間から単位時間に出ていく運動量成 分が検查空間内の流体に及ぼす力の成分に等しくな るという運動量の定理を適用すると、一様断面水路 において横越流を伴う水面形方程式は次式のように 表される\%。

$$
\frac{d y}{d x}=\frac{\sin \theta-\frac{Q^{2}}{C_{0}{ }^{2} R A^{2}}+\frac{\beta_{0} Q q}{g A^{2}}}{\cos \theta-\frac{\beta_{0} Q^{2} B}{g A^{3}}}
$$

ここに、 $C_{0}$ はChézyの定数， $R$ は径深， $A$ は流水 断面積, $\beta_{0}$ は運動量補正係数, $\sin \theta$ は水路床勾配 である。式(8)において水路床勾配と摩擦抵抗の影響 は小さいとして無視すると、堰区間の水路に沿う水 面形方程式は次式のように簡略化される。

$$
\frac{d y}{d x}=\frac{Q q y}{g B^{2} y^{3}-Q^{2}}
$$

式 (9)より流れが全領域で常流の場合には $d y / d x>0$, つまり、流れ方向に水深が増加するこ とがわかる。また、上流側流量を $Q_{1}$, 横越流堰の 堰長を $L$ とし、この堰からの全越流量を $Q_{W}$ とする と、緩勾配水路においては下流側で等流水深に漸近 する水面形は存在しないので、堰の末端流量 $Q_{2}=\left(Q_{1}-Q_{W}\right)$ に対応する等流水深 $h_{02}$ で流れる。 よって、水面形の概要は図-2に示すようになる。

$$
\begin{aligned}
& \text { また、式(1)を変形して次式を得る。 } \\
& \qquad=A v=y(B+m y) \sqrt{2 g(E-y)}
\end{aligned}
$$

式(10)および(7)を式(9)に代入することによって、水 面形方程式は新たに次のように表される。

$$
\frac{d y}{d x}=\frac{4}{3} \frac{C_{M}}{(B+m y)} \frac{\sqrt{(E-y)(y-W)^{3}}}{3 y-2 E}
$$

ここで、流量係数 $C_{M}$ は河道に沿う距離 $x$ に対し て独立であると仮定し、式(11)を次のように変形す る。 


$$
\begin{aligned}
d x= & \frac{3}{4} \frac{(B+m y)}{C_{M}} \frac{3 y-2 E}{\sqrt{(E-y)} \sqrt{(y-W)^{3}}} d y \\
= & \frac{3}{4} \frac{B}{C_{M}} \frac{3 y-2 E}{\sqrt{(E-y)} \sqrt{(y-W)^{3}}} d y \\
& \quad+\frac{3}{4} \frac{m}{C_{M}} \frac{y(3 y-2 E)}{\sqrt{(E-y)} \sqrt{(y-W)^{3}}} d y
\end{aligned}
$$

式(12)の中で、右辺第 1 項は積分することにより De Marchiの式となる項であり、右辺第 2 項は側壁勾配 を考慮したために付加された項である。この式(12) について、越流堰のある $x$ の区間で積分する事を試 みる。右辺第 1 項の積分はDe Marchiの式と同じ結 果が出るため、ここでは右辺第 2 項についてのみを 次式、

$$
d \varsigma=\frac{3}{4} \frac{m}{C_{M}} \frac{y(3 y-2 E)}{\sqrt{(E-y)} \sqrt{(y-W)^{3}}} d y
$$

のように表示して考えることとする。

$$
\text { 式(13)において、 } \sqrt{(E-y) /(y-W)}=t \text { を代入して }
$$

右辺を $t$ の関数にすると、次式が得られる。

$$
d \zeta=\frac{3}{2} \frac{m}{C_{M}} \frac{1}{W-E}\left\{3\left(\frac{t^{2} W+E}{t^{2}+1}\right)^{2}-2 E\left(\frac{t^{2} W+E}{t^{2}+1}\right)\right\} d t
$$

式(14)において、 $t$ に関する部分積分を行い $y$ の関 数に直すと、与は次式となる。

$$
\begin{aligned}
\varsigma=\frac{3}{2} \frac{B m}{C_{M}}\left\langle\frac{1}{B}\left\{\frac{1}{2} E-\frac{9}{2} W\right\} \tan ^{-1} \sqrt{\frac{E-y}{y-W}}\right. \\
\left.+\frac{W(2 E-3 W)}{B(E-W)} \sqrt{\frac{E-y}{y-W}}-\frac{3}{2 B} \sqrt{(E-y)(y-W)}\right\rangle
\end{aligned}
$$

以上のように、式(12)の右辺第2項は式(15)のように 積分できる。式(12)の右辺第1項においても同様の操 作を行うことで積分可能である。ここで、堰上流端 および下流端の添え字をそれぞれ 1,2 とすることに よって堰長 $L$ に関して次式が得られる。

$$
\begin{aligned}
x_{2}-x_{1} & =L \\
= & \frac{3}{2} \frac{B}{C_{M}}\left[\left(\phi_{a 2}-\phi_{a 1}\right)+m\left(\phi_{b 2}-\phi_{b 1}\right)\right] \\
\text { ここで } & \\
\phi_{a}(y, E, W) & =\frac{2 E-3 W}{E-W} \sqrt{\frac{E-y}{y-W}}-3 \tan ^{-1} \sqrt{\frac{E-y}{y-W}} \\
\phi_{b}(y, E, W, B) & =\frac{1}{B}\left\{\frac{1}{2} E-\frac{9}{2} W\right\} \tan ^{-1} \sqrt{\frac{E-y}{y-W}} \\
& +\frac{W(2 E-3 W)}{B(E-W)} \sqrt{\frac{E-y}{y-W}}-\frac{3}{2 B} \sqrt{(E-y)(y-W)}
\end{aligned}
$$

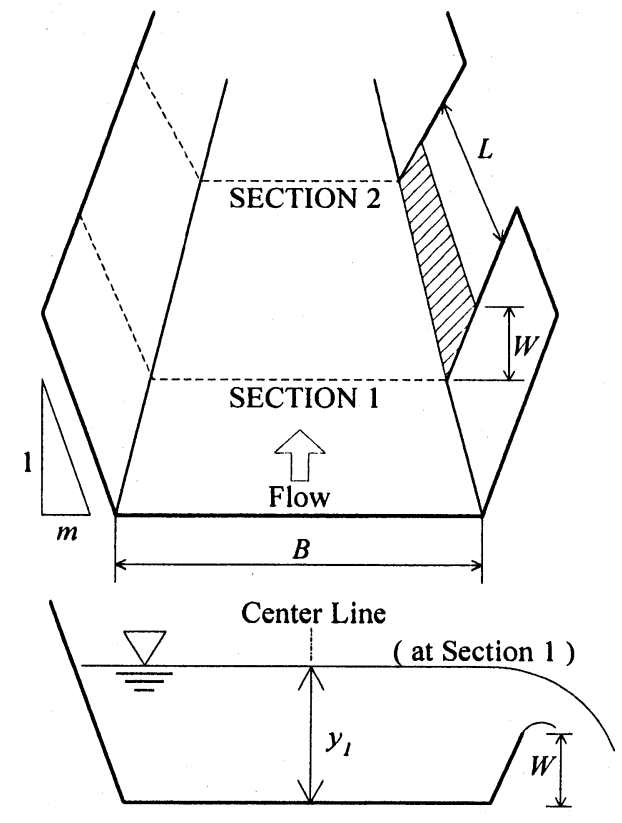

図-3 実験装置

この式(16.a)〜 (16.c)が、台形断面水路内に設置さ れた横越流堰の流量算定式として用いられる。また、 この式における右辺第2項によって台形断面につい て考慮していることを表し、 $m=0$ を代入することに よって矩形断面の場合も包含することがわかる。

ところで、式(16)における流量係数は、式(5)から (6)とするときの接近流速水頭, 式(3)の流速分布の 無視などの仮定・簡略化の効果を含んだものであり、 Subramanya \& Awasthy ${ }^{4}$ は矩形断面の場合に、次元 解析により $C_{M}$ を規定するパラメータとして、流入 点の水路Froude数 $F_{1}$, 相対水深 $W / y_{1}$ および相対堰 長 $L / B$ の3つであることを提案している。しかし側 壁勾配 $m$ の存在は、矩形断面の場合よりそれらの影 響が大きく表れると考えられ、これらのパラメータ に加え $m$ を変化させて実験的に定める必要がある。

\section{3. 実験装置および実験方法}

本実験に用いた水路は長さ $600 \mathrm{~cm}$, 水路の底面幅 $B=11.5 \mathrm{~cm}$ で側壁勾配 $m$ をもつ木製水路である。そ の概要を図-3に示す。横越流堰は、堰高を $W=3 \mathrm{~cm}$ の刃型堰とし、始端を水路入口から $350 \mathrm{~cm}$ の水路右 岸側とした。また本実験の変化パラメータについて は、側壁勾配を $m=0,0.3,0.5,0.7$ として、それ ぞれの $m$ に対して堰の長さを $L=10,15,20 \mathrm{~cm}$ 、流 入水深を $y_{1}=5,7,9 \mathrm{~cm}$ 、流入Froude数を $F_{1}=0.3 \sim$ 0.8 と系統的に変化させた。堰上流端および下流端 
表- 1 実験条件と結果

(表中の， $F_{1} C_{M}$ は、1000倍した值を示している)

\begin{tabular}{|c|c|c|c|c|c|c|c|c|c|}
\hline \multicolumn{2}{|c|}{$m$} & \multicolumn{2}{|c|}{0.00} & \multicolumn{2}{|c|}{0.30} & \multicolumn{2}{|c|}{0.50} & \multicolumn{2}{|c|}{0.70} \\
\hline$L$ & $y_{1}$ & $F_{1}$ & $C_{M}$ & $F_{1}$ & $C_{M}$ & $F_{1}$ & $C_{\mu}$ & $F_{1}$ & $C_{M}$ \\
\hline \multirow{18}{*}{10} & \multirow{6}{*}{5} & 282 & 560 & 313 & 584 & 298 & 564 & 299 & 545 \\
\hline & & 415 & 500 & 402 & 552 & 419 & 502 & 401 & 530 \\
\hline & & 497 & 490 & 490 & 537 & 499 & 517 & 507 & 485 \\
\hline & & 623 & 420 & 622 & 476 & 605 & 508 & 626 & 483 \\
\hline & & - & - & - & - & 704 & 456 & - & - \\
\hline & & - & - & - & - & - & - & - & - \\
\hline & \multirow{6}{*}{7} & 303 & 532 & 303 & 560 & 298 & 573 & 303 & 546 \\
\hline & & 406 & 496 & 395 & 532 & 406 & 558 & 400 & 492 \\
\hline & & 501 & 478 & - & - & 500 & 515 & 493 & 472 \\
\hline & & 602 & 432 & 588 & 459 & 597 & 499 & 605 & 477 \\
\hline & & - & - & - & - & 685 & 482 & 698 & 463 \\
\hline & & - & - & - & - & - & - & - & - \\
\hline & \multirow{6}{*}{9} & 302 & 534 & 305 & 569 & 301 & 583 & - & - \\
\hline & & 397 & 495 & 403 & 521 & 397 & 543 & 395 & 535 \\
\hline & & 496 & 452 & 490 & 532 & 511 & 525 & 506 & 514 \\
\hline & & 604 & 427 & 586 & 463 & 595 & 463 & - & - \\
\hline & & - & - & - & - & - & - & - & $=$ \\
\hline & & - & - & - & - & - & - & - & - \\
\hline \multirow{18}{*}{15} & \multirow{6}{*}{5} & 296 & 558 & 305 & 562 & 312 & 558 & 306 & 528 \\
\hline & & 401 & 521 & 395 & 538 & 398 & 544 & 415 & 518 \\
\hline & & 523 & 471 & 513 & 509 & 506 & 502 & 484 & 476 \\
\hline & & 590 & 453 & 607 & 477 & 593 & 507 & 615 & 480 \\
\hline & & 675 & 435 & - & - & 693 & 508 & 699 & 469 \\
\hline & & 795 & 387 & $=$ & - & 811 & 456 & - & - \\
\hline & \multirow{6}{*}{7} & - & - & 317 & 526 & 298 & 545 & 306 & 542 \\
\hline & & 414 & 499 & 410 & 529 & 403 & 539 & 408 & 506 \\
\hline & & 497 & 490 & 483 & 491 & 499 & 511 & 496 & 473 \\
\hline & & 603 & 426 & 605 & 484 & 602 & 499 & 591 & 468 \\
\hline & & 705 & 399 & - & - & - & - & - & - \\
\hline & & 801 & 341 & - & - & - & $=$ & - & - \\
\hline & \multirow{6}{*}{9} & - & - & - & $=$ & - & - & 300 & 562 \\
\hline & & - & - & 400 & 508 & 399 & 531 & 401 & 512 \\
\hline & & 511 & 466 & 497 & 509 & 500 & 498 & 506 & 477 \\
\hline & & 595 & 432 & - & - & - & - & - & - \\
\hline & & 718 & 388 & - & - & - & - & - & - \\
\hline & & 811 & 337 & - & - & - & - & - & - \\
\hline \multirow{18}{*}{20} & \multirow{6}{*}{5} & - & -1 & 319 & 574 & 306 & 551 & 306 & 544 \\
\hline & & 401 & 521 & 401 & 577 & 404 & 529 & 399 & 527 \\
\hline & & 495 & 492 & 490 & 564 & 489 & 514 & 504 & 505 \\
\hline & & 606 & 455 & - & - & 599 & 501 & 620 & 469 \\
\hline & & 701 & 399 & - & - & 698 & 495 & - & - \\
\hline & & 813 & 378 & - & - & 799 & 434 & $=$ & - \\
\hline & \multirow{6}{*}{7} & - & - & 385 & 564 & $\overline{-}$ & - & - & - \\
\hline & & - & - & 417 & 509 & 396 & 540 & 396 & 527 \\
\hline & & 506 & 494 & 501 & 506 & 504 & 497 & 512 & 497 \\
\hline & & 605 & 448 & 582 & 463 & 598 & 482 & - & - \\
\hline & & 707 & 392 & - & - & 708 & 442 & - & - \\
\hline & & 796 & 360 & - & - & - & - & - & - \\
\hline & & - & - & - & - & - & - & - & - \\
\hline & & - & - & 465 & 505 & 103 & 544 & 394 & 537 \\
\hline & 0 & $\overline{-}$ & - & 502 & 518 & 499 & 507 & 496 & 509 \\
\hline & 9 & 606 & 450 & 609 & 495 & 600 & 463 & - & - \\
\hline & & 707 & 403 & - & - & - & - & - & - \\
\hline & & 799 & 371 & - & - & - & - & - & - \\
\hline
\end{tabular}

の水深 $y_{1}, y_{2}$ は超音波式変位センサで20秒間测定し、 その平均值を用いた。上流侧流量 $Q_{1}$ は四角堤を越 える越流水深を基に、下流側流量 $Q_{2}$ は量水桝の水 位上昇速度を容量式波高計を用いることで算出した。

\section{4．実験結果および考察}

流量係数 $C_{M}$ の実験值は次のように算出できる。 すなわち、実験より得られた堰上流端における $Q_{1}, y_{1}$ を式(1)に代入して $E_{1}$ を計算し、これを用いて 式(16.b)と(16.c)より $\phi_{a 1}, \phi_{b 1}$ を得る。同様にして堰 下流端の $Q_{2}, y_{2}$ より $E_{2} ， \phi_{a 2} ， \phi_{b 2}$ が得られ、これ らより式(16.a)を用いて $C_{M}$ を求めた。

実験より得られた $C_{M}$ と堰上流端におけるFroude 数 $F_{1}=Q_{1} / \sqrt{g y_{1}}\left[y_{1}\left(B+m y_{1}\right)\right]$ を表- 1 に示した。ここ で、この表中の $C_{M}, F_{1}$ はいずれも1000倍した值と して表示している。

$C_{M}$ の值は中川・宇民ら ${ }^{2,3)}$ や Subramanya \& Awasthy) が指摘したように $F_{1}$ の関数であるが、側 壁勾配 $m$ を変化させたために堰長 $L$, 流入水深 $y_{1}$ の影響も考えられる。そこで图ー4にはまず $m$ ごと に $C_{M}$ を $F_{1}$ の関数として表示した。このとき、それ それの $m$ ことに $W / y_{1}$ を $3 / 9 ， 3 / 7 ， 3 / 5$ の一定值の 図として上から(a), (b), (c)で示している。また、こ

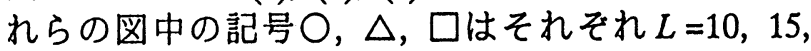
$20 \mathrm{~cm}$ であ。なお、 $m=0$ の矩形断面水路において 図中に示している点線の曲線は、Subramanya \& Awasthy)によって堰高 $W=8 \sim 51 \mathrm{~cm}$ の実験結果を用 いて求められた $F_{1}-C_{M}$ 曲線で、次式で表されるも のである。

$$
C_{M}=0.611 \sqrt{1-\frac{3 F_{1}{ }^{2}}{F_{1}{ }^{2}+2}}
$$

本実験の有効性を見る意味で、実験結果と式(17)を 比較するとほぼ同一の值を示しており、今回の実験 結果は有効であるといえる。

図-4より $F_{1}=0.3 \sim 0.8$ 範囲においては、記号の 違い、すなわち $L$ の違いによる系統的な差は見られ ない。そこで、これらのデータを用いて最小二乗法 により $C_{M}$ と $F_{1}$ を次式(18)の1次関数で表し心また これらの各式をそれそれ図中に示した。

$$
C_{M}=\alpha \cdot F_{1}+\beta
$$

これらから、傾き $\alpha$ は $W / y_{1}$ に独立で $m$ のみの関数 であるといえる。

一方、切片 $\beta$ は $m$ のみならず $W / y_{1}$ にも依存して いるようである。そこで、 $m=$ const.のもとで $\beta$ と $W / y_{1}$ の関係を表したものが図-5(a)〜(d)である。 しかし、これらの図から $\beta$ は実測值のばらつきが大 きいため $W / y_{1}$ への依存性を確かめることは難しく、 むしろ $m$ に関する依存性が大きい。 


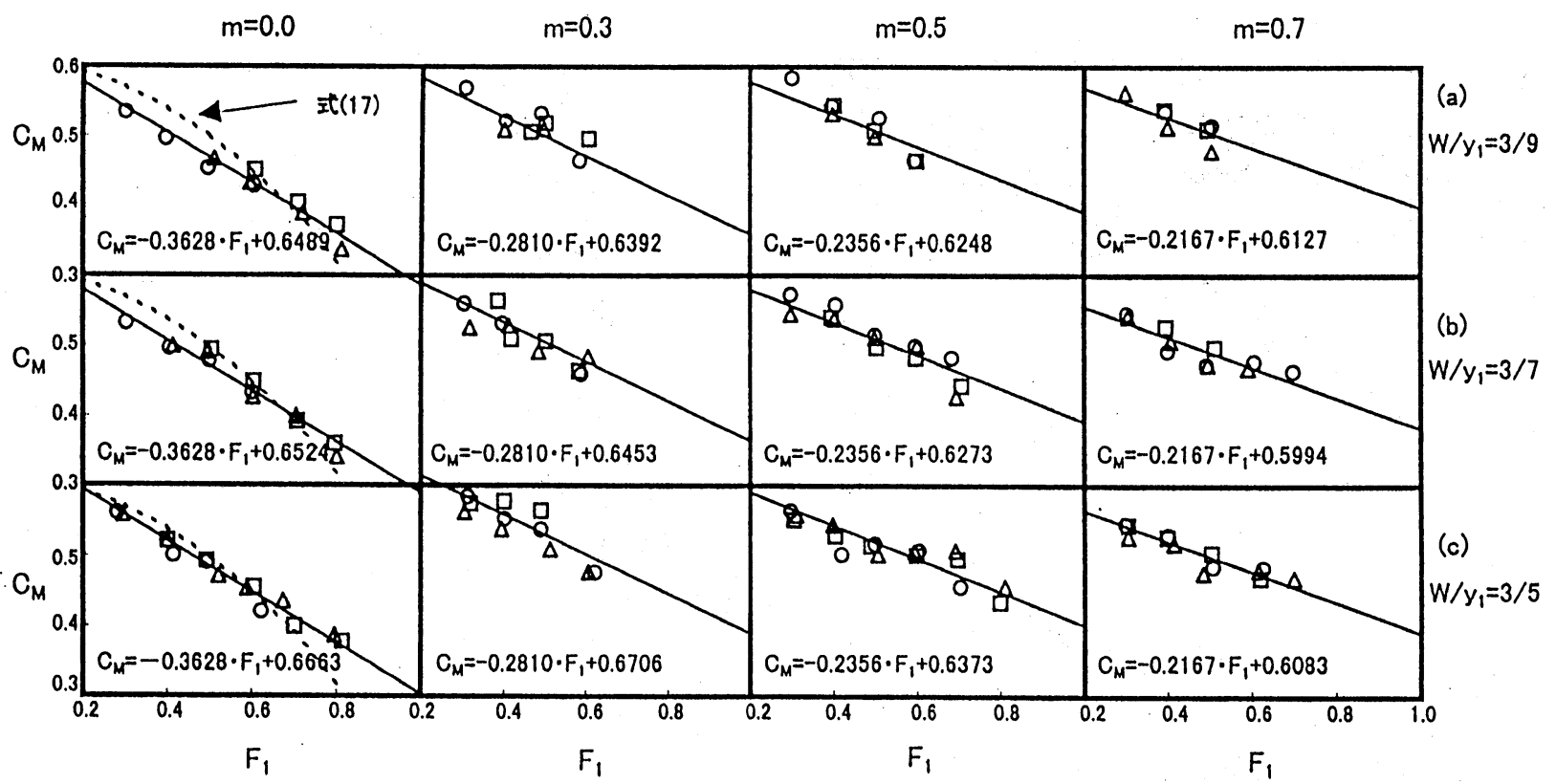

図-4 流入 Froude 数 $F_{1}$ と流量係数 $C_{M}$ の関係

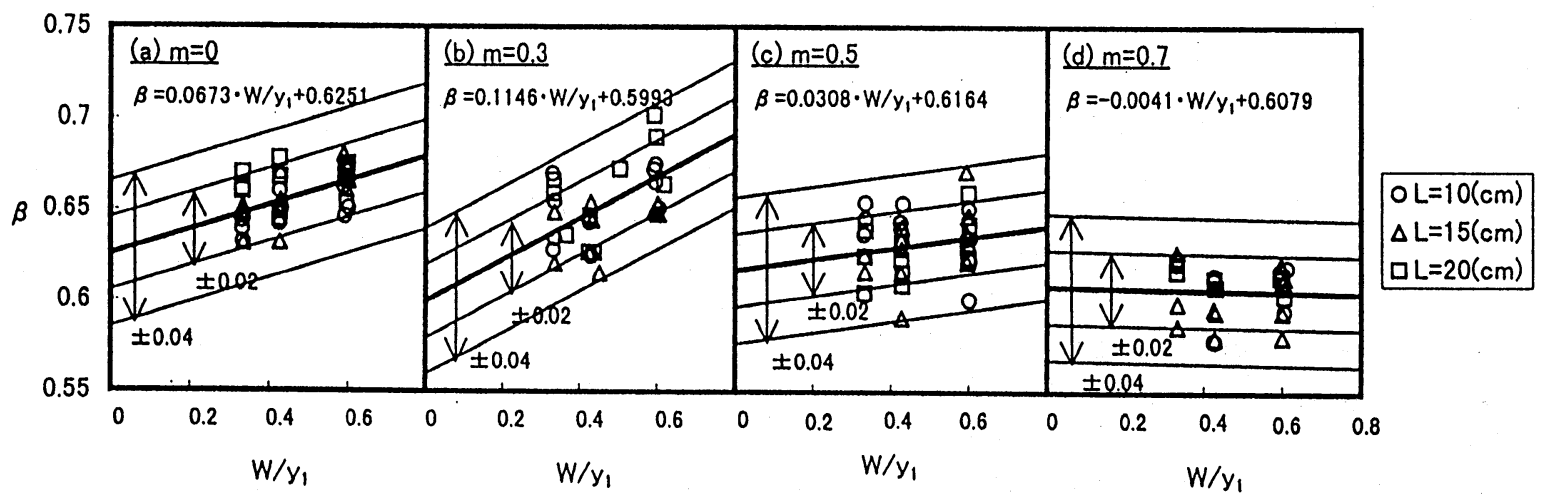

図-5 相対水深 $W / y_{1}$ と切片 $\beta$ の関係

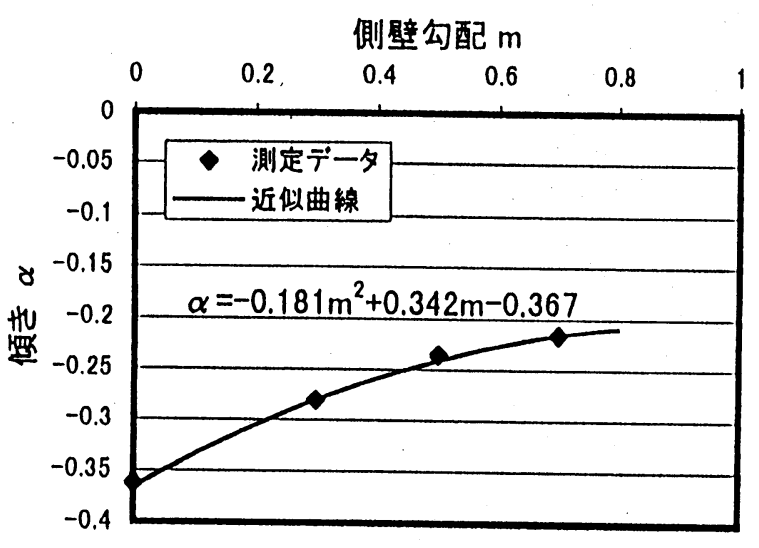

図-6 侧壁勾配 $m$ と傾き $\alpha$ の関係

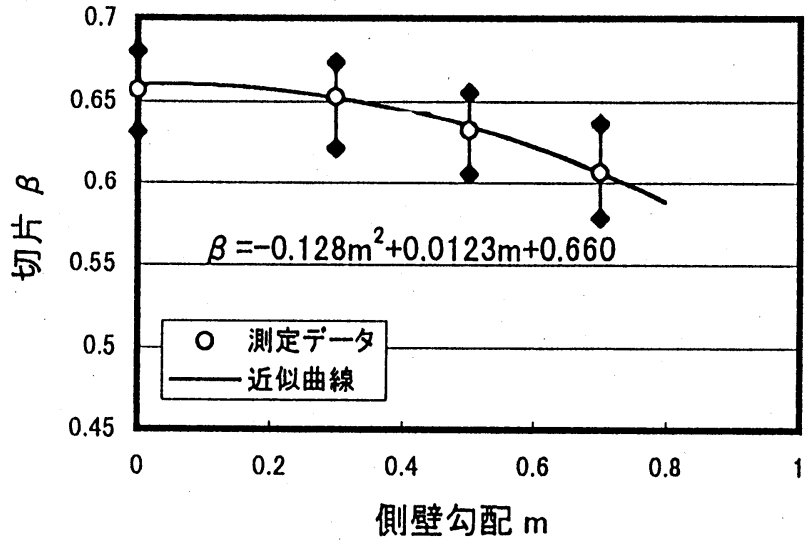

図-7 侧壁勾配 $m$ と傾き $\beta$ の関係 


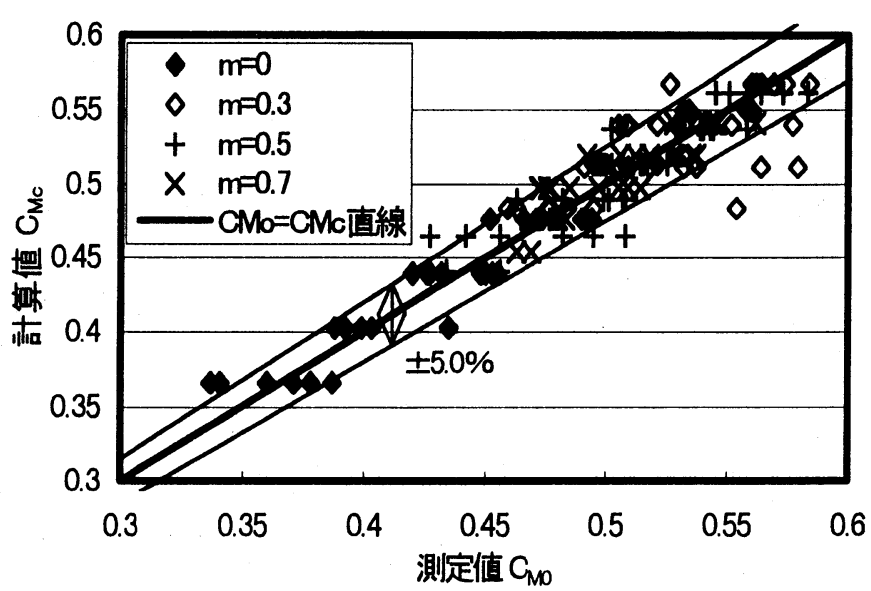

図-8 実測值 $C_{M_{0}}$ と計算值 $C_{M c}$ との関係

そこで、図-4 中に示した式(18)の $\alpha$ と $m$ との関 係を図-6に示す。これより、 $\alpha$ は $m$ の2次関数とし て近似でき、次式で表される。

$$
\alpha=-0.181 m^{2}+0.342 m-0.367
$$

次に、式(15)を各実験デー夕に適用して $\beta$ を求め、 $m$ との関係を表したものが図-7である。図中には $\beta$ の実測值のばらつきがわかるように $\beta$ の最大值と 最小值をけ印で示した。よって図-7より $\beta$ は、

$$
\beta=-0.128 m^{2}+0.0123 m+0.660
$$

で近似できる。よって側壁勾配を持つ横越流堰の実 験結果より、 $C_{M}$ は式(18), (19)および(20)で近似で きる。図-8に式(18), (19)および(20)より求めた計算 值 $C_{M c}$ と実測值 $C_{M_{0}}$ とを示した。この図には土 $5.0 \%$ の誤差の範囲を直線で示した。図-8より、 印で表した $m=0.3, W / y_{1}=3 / 5$ のデー夕を除けば、 $C_{M}$ はそのほとんどが誤差 $\pm 5.0 \%$ の範囲で式(18), (19)および(20)で表すことができるといえる。

\section{5.おわりに}

台形断面を有する水路内に横越流堰が設置された とき、それぞれ以下ことがいえた (式(18)〜(20)に ついては文末を参照)。

(1) 台形断面水路における横越流堰からの越流量は 式(16.a)〜(16.c)を用いることによって計算可能とな る。
（2） $C_{M}$ は、流入点の水路Froude数 $F_{1}$ に大きく依存 し、これは従来の矩形断面の研究と一致する。また $C_{M}$ を式(18)のように $F_{1}$ の1次関数で表すとき、そ の傾き $\alpha$ は $m=0 \sim 0.7$ のき $F_{1}=0.2 \sim 0.8$ の範囲にお いて $m$ にのみ依存するパラメータであり、式(19)の ように $m$ の2次関数で表される。

(3) 式(18)における切片 $\beta$ は、 $W / y_{1}$ に若干依存す る傾向が見られるが、この判定については測定デー 夕の精度に大きく影響されるため、依存性を確かめ るのは難しい。

(4) 各実験データを式(18)に代入し、各データの切 片 $\beta$ の值を一定とすると、この $\beta$ は $m$ の 2 次関数で 表される。

(5) 式(18)，(19)および(20)で求められる $C_{M}$ の計算 值 $C_{M c}$ は、本実験における実験值 $C_{M_{0}}$ と $\pm 5.0 \%$ の 誤差で一致する。

$$
\begin{gathered}
C_{M}=\alpha \cdot F_{1}+\beta \\
\alpha=-0.181 m^{2}+0.342 m-0.367 \\
\beta=-0.128 m^{2}+0.0123 m+0.660
\end{gathered}
$$

謝辞 : 本研究を行うに当たり、実験および資料整理 に協力いただいた本学大学院生・堀越公博、本学学 部生・藤健志，大柴康子，澤田尚人の諸氏に謝意を 表します。

\section{参考文献}

1) De Marchi, G. :Essay on the performance of lateral weirs, L.Energia Elettrica, Milan, Italy, 11, pp.849-860, 1934.

2) 中川博次，宇民正 : 横越流分水工の機能設計に関す る研究, 京都大学防災研究所年報第9号, pp.539-550, 1966.

3) 土木学会編: 水理公式集（昭和60年度版）, 土木学会, p.292, 1985 .

4) Subramanya, K., and Awasthy, S.C. :Spatially varied flow over side weir, Journal of the Hydraulics Division, ASCE, Vol.98, No.1, pp.1-10, 1972.

5) 坂本真, 小野博基, 浦 勝, 秋山壽一郎, 河内俊 雄 : 台形断面水路内の横越流㘿の流量係数について, 平成8年度土木学会西部支部研究発表会 講演概要集, pp.234-235, 1997.

6) 椿東一郎: 水理学 I, 森北出版, p.169-170, 1973.

(1997.9.30受付) 